\title{
Coronin-1 and Calcium Signaling Governs Sympathetic Final Target Innervation
}

\author{
DDong Suo, ${ }^{1}$ Juyeon Park, ${ }^{1}$-Samuel Young, ${ }^{1}$ Takako Makita, ${ }^{2}$ and Christopher D. Deppmann ${ }^{1,3,4}$ \\ ${ }^{1}$ Department of Biology, University of Virginia, Charlottesville, Virginia 22903, ${ }^{2}$ Developmental Neuroscience Program, The Saban Research Institute, \\ Children's Hospital Los Angeles, University of Southern California Keck School of Medicine, Los Angeles, California 90027, and ${ }^{3}$ Departments of Cell \\ Biology and ${ }^{4}$ Biomedical Engineering, University of Virginia, Charlottesville, Virginia 22903
}

Development of a functional peripheral nervous system requires axons to rapidly innervate and arborize into final target organs and then slow but not halt their growth to establish stable connections while keeping pace with organ growth. Here we examine the role of the NGF-TrkA effector protein, Coronin-1, on postganglionic sympathetic neuron final target innervation. In the absence of Coronin-1 we find that NGF-TrkA-PI3K signaling drives robust axon growth and branching in part by suppressing GSK3 $\beta$. In contrast, the presence of Coronin-1 (wild-type neurons) suppresses but does not halt NGF-TrkA-dependent growth and branching. This relative suppression in axon growth behaviors is due to Coronin-1-dependent calcium release via PLC- $\gamma 1$ signaling, which releases PI3K-dependent suppression of GSK3 $\beta$. Finally, we demonstrate that Corola $a^{-/-}$mice display sympathetic axon overgrowth and overbranching phenotypes in the developing heart. Together with previous work demonstrating the Coronin-1 expression is NGF dependent, this work suggests that periods before and after NGF-TrkA-induced Coronin-1 expression (and likely other factors) defines two distinct axon growth states, which are critical for proper circuit formation in the sympathetic nervous system.

Key words: branching; calcium; Coronin-1; NGF; PI3K; TrkA

\section{Introduction}

Wiring a functional nervous system during development requires axons to make several choices and change behaviors as they transition between intermediate targets (e.g., blood vessels) and eventually into a final target (e.g., heart, muscle, and eye). The sympathetic nervous system represents a relatively simple paradigm to study how these axons change their behavior en route to their final destination. Sympathetic axons grow along their intermediate targets in fascicles indicating that they likely experience signaling that suppresses branching and turning (Carmeliet, 2003). However, upon arrival to their final targets, axons must become much more dynamic to achieve proper coverage of the organ indicating another switch in axonal signaling properties. After this robust period of NGF-TrkA-dependent growth and branching in sympathetic final targets, these processes are dampened suggesting another change in axonal signaling (Kohn et al., 1999; Singh et al., 2008; Manousiouthakis et al., 2014). Impor-

\footnotetext{
Received 0ct. 23, 2014; revised Dec. 30, 2014; accepted Jan. 26, 2015.

Author contributions: D.S. and C.D.D. designed research; D.S., J.P., S.Y., and T.M. performed research; D.S. and C.D.D. analyzed data; D.S. and C.D.D. wrote the paper.

T.M. was supported by National Institutes of Health (NIH)-National Institute of Neurological Disorders and Stroke (NINDS; R01NS083265). C.D.D. was supported by the Sloan Foundation, UVa Fund for Excellence in Science and Technology, and NIH-NINDS (1R01NS072388). We thank Jean Pieters for providing Coro1a ${ }^{-1-}$ mice. We also thank Pam Neff and the Keck Center for biological imaging for technical support. We are grateful to Irene Cheng, Barry Condron, Ali Guler, Anthony Harrington, Kanchana Gamage, Rejji Kuruvilla, Sarah Siegrist, Laura Sipe, Nikki Watson, Michael Wheeler, and Kevin Wright for helpful discussion.

The authors declare no competing financial interests.

Correspondence should be addressed to Christopher Deppmann, Departments of Biology, Cell Biology, and Biomedical Engineering, University of Virginia, Charlottesville, VA 22904-4328. E-mail: deppmann@virginia.edu.

DOI:10.1523/JNEUROSCI.4402-14.2015

Copyright $\odot 2015$ the authors $\quad 0270-6474 / 15 / 353893-10 \$ 15.00 / 0$
}

tantly, NGF-TrkA signaling appears to be required for axon growth and ramification during both early and late stages of final target innervation but not for growth along the intermediate target (Glebova and Ginty, 2004; Kuruvilla et al., 2004; Nam et al., 2013). Herein, we explore the molecular basis by which NGFTrkA-dependent sympathetic axon growth properties change during final target innervation.

Coronin-1 is an NGF-dependent gene, dynamically changing from undetectable before sympathetic final target innervation to high expression after neurons encounter NGF (Deppmann et al., 2008; Suo et al., 2014). Coronin-1 is known to regulate both calcium and cAMP-dependent signaling pathways in response to stimuli ranging from pathogen infection to learning paradigms (Jayachandran et al., 2007, 2014). Calcium and cAMP have also been reported to influence axon growth behavior (Song et al., 1997; Henley and Poo, 2004; Gomez and Zheng, 2006). The remarkable NGF dependence of Coronin-1 expression along with the notion that Coronin-1 regulates several signaling pathways known to influence axon growth makes this an attractive candidate for a molecular switch influencing final target innervation. Moreover, the finding that loss of Coronin-1 uncouples NGFTrkA from calcium signaling provides a powerful tool as we seek to dissect the signaling pathways underlying sympathetic nervous system development (Suo et al., 2014).

In this study, we provide in vitro and in vivo evidence that Coronin-1 acts as a molecular switch required for sympathetic axons to change their growth properties in final target organs: (1) its expression changes from undetectable to robust levels upon final target innervation and exposure to NGF (Suo et al., 2014); (2) its upregulation corresponds to a switch from primarily PI3K- 
influenced to calcium-influenced axon growth, branching, and growth cone morphology; and (3) the NGF-TrkA-Coronin-1calcium signaling axis is required to slow axon growth and repress branching via disinhibition of GSK3 $\beta$ as axons approach their final destination.

\section{Materials and Methods}

Reagents. Antibodies were previously validated for the applications used. The dilutions and applications were as follows: Coronin-1a (Abcam, ab53395; 1:400 for immunohistochemistry), Tubb3 (Covance, MMS435P-250; 1:400 for immunohistochemistry), rhodamine phalloidin (Life Technologies, R-4150; 1:400 for immunohistochemistry), phospho-p44/42 MAPK (Erk1/2) mouse mAb (Cell Signaling Technology, \#9106; 1:1000 for Western blot), pan-p44/42 MAPK (Erk1/2) antibody (Cell Signaling Technology, \#9102s; 1:1000 for Western blot), anti-tyrosine hydroxylase (Millipore, AB1542; 1:130 for immunohistochemistry), horseradish peroxidase-conjugated donkey anti-sheep IgG (Fisher/Jackson ImmunoResearch, NC9754415; 1:250), 3,3'-diaminobenzidine tetrahydrochloride tablet (Sigma, D5905-50TAB; 1 tablet/20 ml for staining), neurotrophin 3 (Millipore, GF031), U-73122 (Sigma, U6756), GSK3 $\beta$ inhibitor XIX (Millipore, 361565), ionomycin (Sigma, I9657), BAPTA-AM (Invitrogen, B-1205), LY294002 (Sigma, L9908), BEZ235 (Selleckchem, S1009), and PD0325901 (Selleckchem, S1036).

Animals. All animal protocols followed are as described previously (Suo et al., 2014) and were conducted in accordance with the Association for Assessment of Laboratory Animal Care Policies and approved by the University of Virginia Animal Care and Use Committee. Sprague Dawley rats were purchased from Harlan. Sympathetic neurons were dissected from $\mathrm{P} 0-\mathrm{P} 2$ rats or mice of either sex as previously described (Zareen and Greene, 2009). All mice were in a C57BL/6 background and J. Pieters generously provided the Corola ${ }^{-1-}$ mice. Genotyping was performed as described previously (Jayachandran et al., 2007).

Tissue culture. Sympathetic neuron cultures were plated as previously described (Deppmann, 2008). Mass culture and microfluidic culture media was DMEM containing $10 \%$ FBS, penicillin-streptomycin (1 U $\mathrm{ml}^{-1}$ ), and $2 \mathrm{ng} \mathrm{ml}^{-1}$ of mouse salivary gland-purified NGF (Kuruvilla et al., 2004; Park et al., 2006). Aphidicolin was applied for $48 \mathrm{~h}$ after plating to remove glia contamination.

Immunocytochemistry. Immunocytochemistry and immunohistochemistry were performed as previously described (Sharma et al., 2010). At room temperature samples were fixed by $4 \%$ paraformaldehyde and blocked for $30 \mathrm{~min}$ using $5 \%$ goat serum and $0.05 \%$ Triton X-100 in PBS. Next, primary antibody was applied overnight at $4^{\circ} \mathrm{C}$. Secondary antibody was applied for $1 \mathrm{~h}$ at room temperature. Samples were washed three times using $1 \times$ PBS and mounted in Vectashield Fluoromount. Images were collected using confocal microscopy.

Immunoblot analysis. Immunoblot analysis was performed as previously described (Suo et al., 2014). Briefly, sympathetic neurons were harvested by boiling in $2 \times$ Laemmli buffer for $10 \mathrm{~min}$. SDS-PAGE followed by Western blot analysis was performed using the indicated antibodies and LI-COR for visualization.

Microfluidic devices. The microfluidic devices used, were as previously described (Park et al., 2006). Chambers were attached to glass coverslips coated with poly-D-lysine $(50 \mu \mathrm{g} / \mathrm{ml})$ and laminin $(1 \mu \mathrm{g} / \mathrm{ml})$. A $100 \mu \mathrm{l}$ volume difference was maintained between two compartments to ensure fluidic isolation.

Axon growth assay. P0-P3 sympathetic superior cervical ganglia (SCG) neurons were plated in the cell body chamber of a microfluidic device in the presence of NGF and aphidicolin $(5 \mu \mathrm{M})$. After 2-3 d axons emerged in the distal axon chamber of the microfluidic device at which time NGF was deprived for $17 \mathrm{~h}$ by adding anti-NGF and boc-aspartyl-(OMe)fluoromethyl-ketone (BAF; $5 \mu \mathrm{M}$ ). The axon chamber media was then changed to anti-NGF $(1 \mu \mathrm{g} / \mathrm{ml})$ or NGF $(2 \mathrm{ng} / \mathrm{ml})$ and images of the entire distal axon chamber field were acquired at this "zero time point." After $24 \mathrm{~h}$, images of the same axons were re-acquired and axon growth rates were quantified as the difference between the two datasets.

Growth cone staining. Staining protocol was adapted from previous studies by Marsick and Letourneau (2011). Coverslips were coated with laminin $(40 \mu \mathrm{g} / \mathrm{ml})$ for $2 \mathrm{~h}$ before plating. P0-P3 sympathetic neurons were plated in mass culture with anti-NGF $(1 \mu \mathrm{g} / \mathrm{ml})$ with BAF $(5 \mu \mathrm{M})$ or NGF $(2 \mathrm{ng} / \mathrm{ml})$. After $1 \mathrm{~d}$ in culture at $37^{\circ} \mathrm{C}$ neurons were fixed with $4 \%$ PFA containing $\mathrm{Ca}^{2+}(1.5 \mathrm{~mm})$ and $\mathrm{Mg}^{2+}(1 \mathrm{~mm})$. Double immunostaining was then performed with Tuj1 and phalloidin. Images were acquired using $63 \times$ confocal microscopy.

Branch assay. $\mathrm{P} 0-\mathrm{P} 3$ sympathetic neurons were plated in mass culture under NGF $(2 \mathrm{ng} / \mathrm{ml})$ or other treatment as indicated. After $1 \mathrm{~d}$ in culture at $37^{\circ} \mathrm{C}$, neurons were fixed with $4 \%$ PFA. Double immunostaining was then performed with Tuj1. Images were taken using $10 \times$ confocal microscopy and analyzed by Sholl analysis.

Whole-mount TH immunohistochemistry. Whole-mount TH immunohistochemistry was performed as previously described (Enomoto et al., 2001). Briefly, samples were incubated with sheep anti-TH affinitypurified polyclonal antibody (Millipore) at $0.5 \mu \mathrm{g} / \mathrm{ml}$ for $72 \mathrm{~h}$ at $4^{\circ} \mathrm{C}$. Next horseradish peroxidase-conjugated donkey anti-sheep IgG $(4 \mu \mathrm{g} /$ $\mu \mathrm{l}$ ) was applied overnight at $4^{\circ} \mathrm{C}$. Next DAB was applied for visualization.

\section{Results}

\section{Coronin-1 acts as a molecular switch that dampens NGF- dependent axon growth, growth cone morphology, and branching}

We investigated whether Coronin-1 plays a role in governing axon behavior in vitro. Toward this end sympathetic neurons from WT $\left(\right.$ Corola $\left.^{+/+}\right)$or Corola $a^{-/-}$mice were established in microfluidic devices to separate axons from cell bodies and provide easily identifiable landmarks to find the same axon from day to day (Park et al., 2006). All neurons were established in 45 $\mathrm{ng} / \mathrm{ml}$ NGF, which is sufficient to support Coronin-1 expression (Suo et al., 2014), until axons traversed the microgrooves. Under fluidic isolation, $2 \mathrm{ng} / \mathrm{ml} \mathrm{NGF}$ was added exclusively to distal axons, while the cell bodies and proximal axons were treated with anti-NGF and a broad-spectrum caspase inhibitor, BAF, to prevent apoptosis. Positive and negative growth of individual axons was measured over a $24 \mathrm{~h}$ period. Remarkably, neurons from

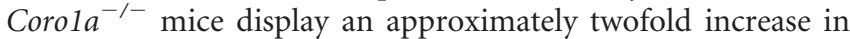
NGF-dependent axon growth compared with WT $\left(\right.$ Corola $\left.^{+/+}\right)$ neurons (Fig. 1 $A, B$ ).

NGF has also been shown to regulate growth cone size, which relates to axon growth rate (Argiro et al., 1984; Bray and Chapman, 1985). Therefore, we next examined growth cone area in NGF-treated neurons from WT and Corola $a^{-/-}$mice. These neurons were grown in mass culture for 1 DIV followed by immunocytochemistry for $\beta 3$-tubulin and phalloidin staining (F-actin). As reported previously, growth cones of WT neurons without neurotrophin were collapsed consistent with a retraction bulb, whereas NGF-treated neurons displayed larger bulbous tips (Fig. 1C,D; Seeley and Greene, 1983; Kuruvilla et al., 2004; Harrington et al., 2011). In contrast, neurons from Coro $1 a^{-/-}$mice displayed an approximately fourfold decrease in growth cone area (Fig. $1 C, D)$. It has been previously suggested that smaller, simpler growth cones appear to correspond with faster axon growth, while larger growth cones appear to be more dynamic, often paused and poised to make choices with respect to directionality and termination in response to instructive environmental cues (Godement et al., 1994). This notion is consistent with accelerated axon growth observed in the absence of Coronin-1 (Fig. 1B).

We next examined the role of Coronin-1 in NGF-dependent axon branching. Sympathetic neurons from P0 WT or Corola ${ }^{-/-}$ mice were cultured in low-density for 1 DIV in the presence of 2 $\mathrm{ng} / \mathrm{ml}$ NGF. Neurons were immunostained for $\beta 3$-tubulin and branching was assessed via Sholl analysis as previously described (Magariños et al., 2006). Consistent with axon growth and growth cone area analyses, the ability of NGF to induce branching 
A
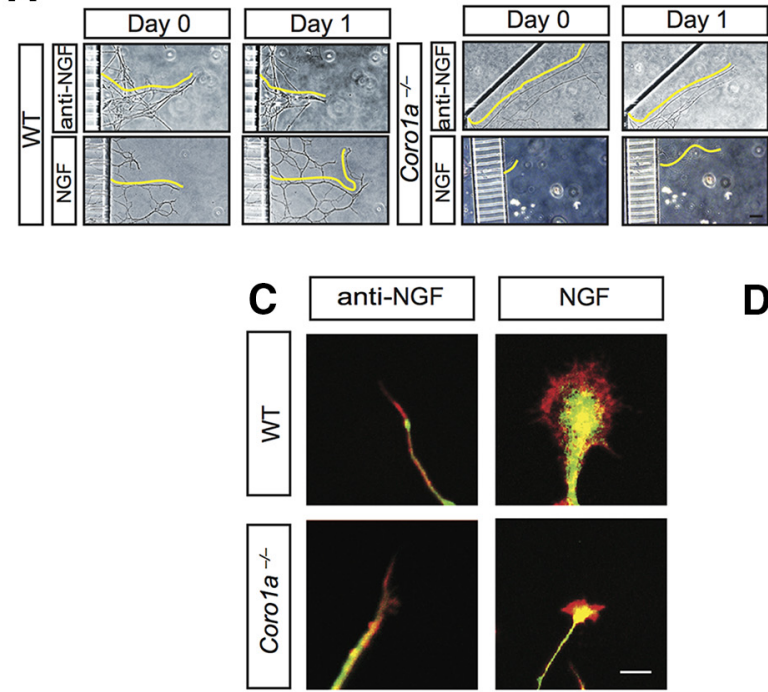

D

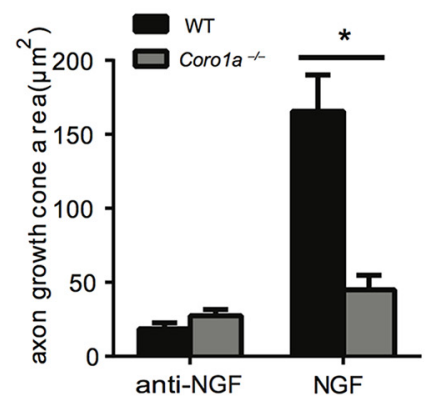

\section{E}
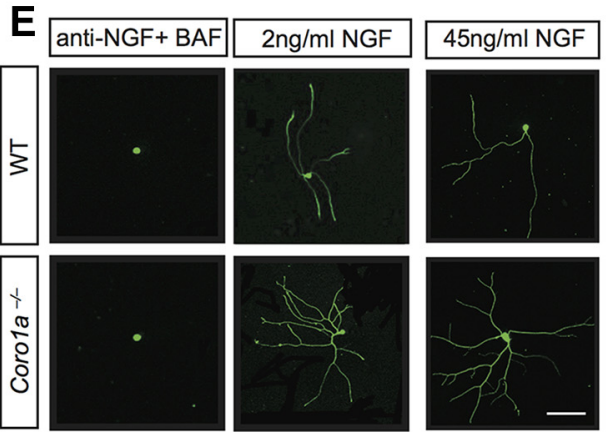

$\mathbf{F}$

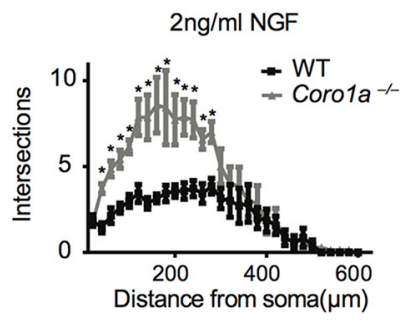

G

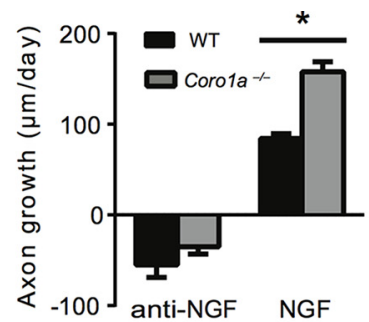

Figure 1. Coronin-1 is a molecular switch for NGF-dependent axon growth, growth cone morphology, and branching behaviors. $A$, Distal axon chamber pictures showing the axons at time 0 and $24 \mathrm{~h}$ (day 1$)$ in neurons cultured in the presence of global anti-NGF $(1 \mu \mathrm{g} / \mathrm{ml})$ or NGF $(2 \mathrm{ng} / \mathrm{ml})$ on the distal axon. Scale bar, $30 \mu \mathrm{m}$. B, Quantification of the rate of axon growth from $A$. WT with NGF $(n=66)$ and WT with anti-NGF $(n=17)$. Coro $1 a^{-1-}$ with NGF $(n=59)$ and Coro $1 a^{-1-}$ with anti-NGF $(n=13)$. C, Neurons were cultured in the presence of anti-NGF $(1 \mu \mathrm{g} / \mathrm{ml})$ or NGF $(2 \mathrm{ng} / \mathrm{ml})$. Neurons from WT or Coro $1 a^{-1-}$ mice were cultured for 1 DIV with NGF or anti-NGF and stained for $\beta 3$-tubulin (green) and actin (red). Scale bar, $10 \mu \mathrm{m}$. D, Quantification of growth cone area from $\boldsymbol{C}(n=15)$. $\boldsymbol{E}$, NGF-induced axon branching patterns in the presence or absence of Coronin-1. Neurons from WT or Coro $1 a^{-1-}$ mice were cultured for 1 DIV in the presence of anti-NGF (1 $\left.\mu \mathrm{g} / \mathrm{ml}\right)$ $+\mathrm{BAF}(5 \mu \mathrm{m}), \mathrm{NGF}(2 \mathrm{ng} / \mathrm{ml})$, or NGF $(45 \mathrm{ng} / \mathrm{ml})$. Tuj 1 immunostaining was performed after $1 \mathrm{~d}$ of plating. Scale bar, $150 \mu \mathrm{m}$. $\boldsymbol{F}, \boldsymbol{G}$, Sholl analysis quantification of $\boldsymbol{E}(n=7)$. Error bars represent SEM; ${ }^{*} p<0.05$ using unpaired two-tailed Student's $t$ test.

is dramatically increased in the absence of Coronin-1 relative to WT neurons (Fig. 1E,F). This apparent role for Coronin-1 in regulating NGF-dependent branching does not appear to be dependent on neurotrophin concentration, since we observe a similar trend using $45 \mathrm{ng} / \mathrm{ml} \mathrm{NGF}$ (Fig. 1E,G). These data suggest that Coronin-1 is required to regulate sympathetic axon growth rate, growth cone size, and branching.

PI3K signaling promotes axon growth and branching in the absence of Coronin-1

We next sought to determine whether Coronin-1 influences classic TrkA-dependent pathways known to be involved in axon growth and branching including Ras-MAPK, PI3K, and/or PLC$\gamma 1$-calcium (Arévalo and Wu, 2006). NGF-dependent PI3K signaling has also been shown to promote axon growth in TrkA+ sensory neurons (Zhou et al., 2004). We asked whether Coronin-1 influences NGF-TrkA-dependent PI3K activation by assessing phospho-AKT levels in cultured sympathetic neurons as described in Figure $1 A$ and $B$. NGF induces p-AKT to similar extents in both WT and Coro $1 a^{-1-}$ neurons (Fig. $2 A, B$ ). We then examined whether PI3K signaling is required for regulating axon behaviors in the absence or presence of Coronin-1. We first per- formed axon growth assays as described in Figure 1, $A$ and $B$, in the presence or absence of PI3K inhibitors, LY290002 $(50 \mu \mathrm{M})$ or BEZ235 ( $1 \mu \mathrm{M})$. Remarkably, both inhibitors suppress the robust NGF-dependent axon growth and branching observed in Coro $1 a^{-/-}$neurons but had no effect on WT neurons (Fig. 2C$G)$. These data suggest that PI3K signaling is necessary for the exuberant axon growth and branching in the absence of Coronin-1 but is dispensable in the presence of Coronin-1 (WT neurons). Importantly, NGF activates PI3K to similar extents in WT and Corola $a^{-/-}$neurons. Therefore, we speculate that Coronin-1 blocks PI3K-dependent axon growth downstream AKT phosphorylation. PI3K/AKT is known to promote axon growth in part via an inhibitory downstream phosphorylation event on GSK3 $\beta$ (Goold et al., 2004). Inhibition of GSK3 $\beta$ allows for the full activity of adenomatous polyposis coli (APC), a microtubule plus end binding protein known to promote axon growth in sensory neurons (Zhou et al., 2004). Below, we explore the possibility that the presence of Coronin-1 blocks NGFinduced GSK3 $\beta$ phosphorylation, which would explain dampened axon growth behaviors in WT neurons relative to Corola $a^{-/-}$neurons. 
A

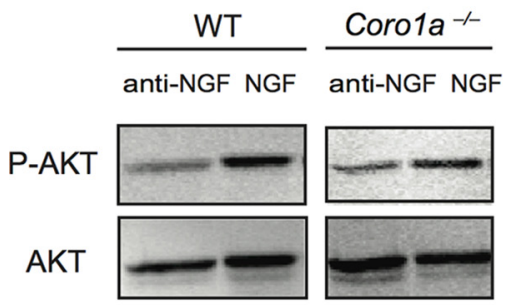

B

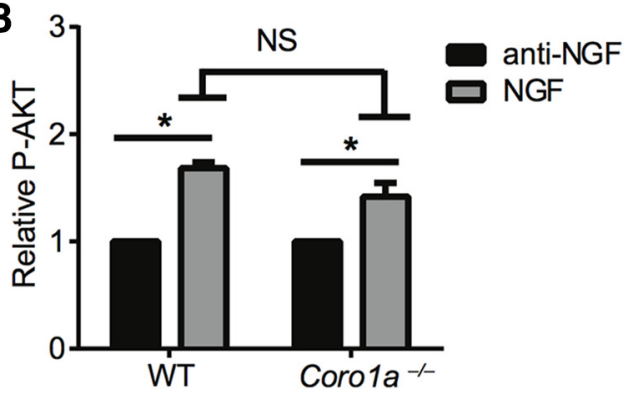

C

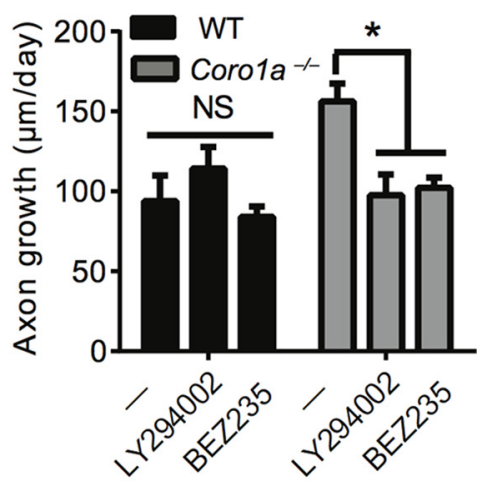

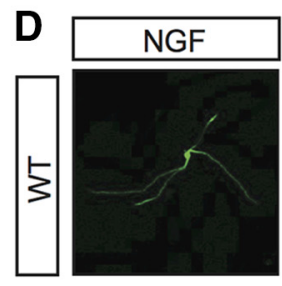
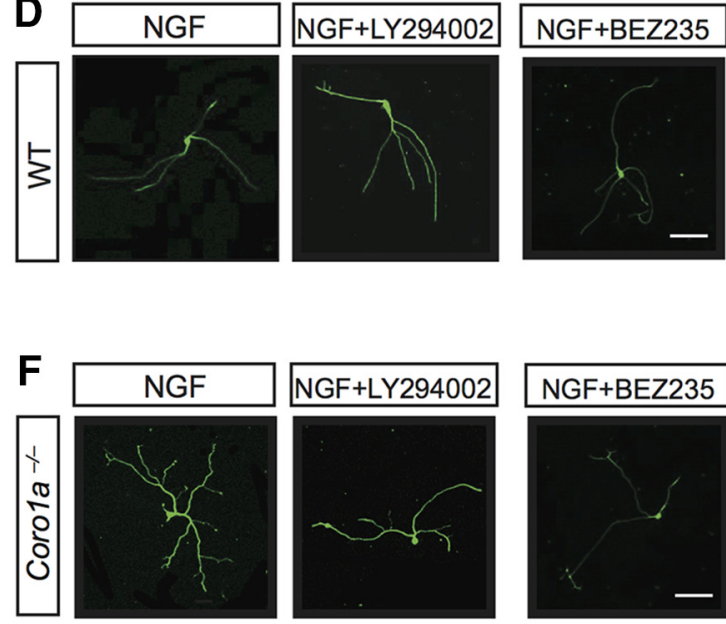

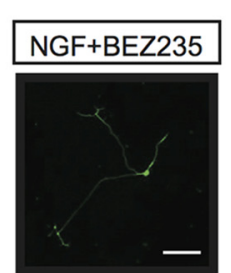

E
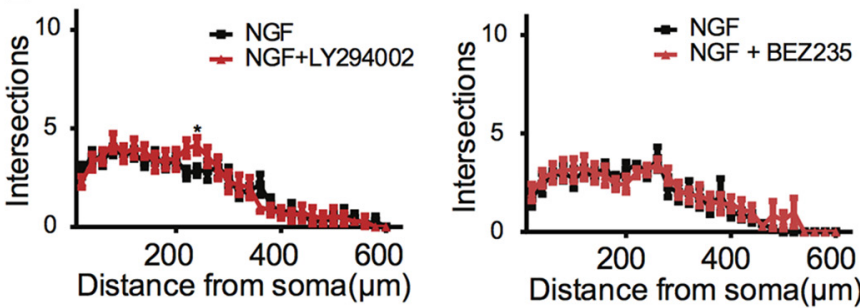

G

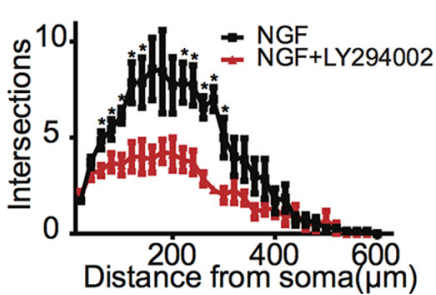

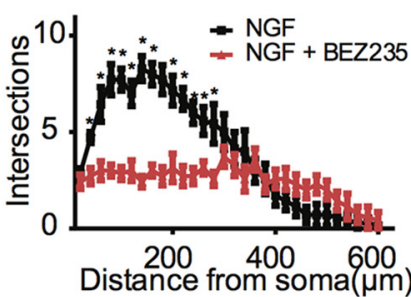

Figure 2. PI3K signaling drives exuberant axon growth and branching in the absence of Coronin-1. $A$, NGF-dependent P-AKT induction in sympathetic neurons cultured from WT or Coro $1 a^{-/-}$ mice for 2-3 DIV. Neurons were deprived of NGF for $17 \mathrm{~h}$ then treated with anti-NGF or NGF for 20 min followed by immunoblot analysis for P-AKT and AKT. $\boldsymbol{B}$, Quantification of the data in $\boldsymbol{A}$. Experiments were quantified with densitometry and P-AKT signals were normalized to total AKT, respectively $(n=3)$. $C$, PI3K signaling is required for NGF-induced axon growth in Coro $1 a^{-/-}$but not WT neurons. Axon growth assays were performed on neurons from WT or Coro $1 a^{-1-}$ mice grown in NGF ( $\left.2 \mathrm{ng} / \mathrm{ml}\right)$ with or without LY294002 (50 $\left.\mu \mathrm{M}\right)$ and BEZ235 (1 $\left.\mu \mathrm{M}\right)$ as described in Figure $1 B$. WT control $(n=46)$, WT with LY294002 and NGF $(n=31)$, WT with BEZ235 and NGF $(n=23)$, Coro 1a $a^{-/}$control $(n=39)$, Coro1a $a^{-/-}$with LY294002 and NGF $(n=25)$, and Coro1a $a^{-/-}$ with BEZ235 and NGF $(n=25) . \boldsymbol{D}, \boldsymbol{F}, \mathrm{PI} 3 \mathrm{~K}$ signaling is required to promote exuberant branching in Coro $1 a^{-/-}$but not WT neurons. Branching of WT or Coro $1 a^{-/-}$mice grown in NGF $(2 \mathrm{ng} / \mathrm{ml})$ with or without LY294002 (50 $\mu \mathrm{m})$ and BEZ235 $(1 \mu \mathrm{m})$ as described in Figure $1 F$. Scale bar, $150 \mu \mathrm{m}$. $\boldsymbol{E}, \mathbf{G}$, Sholl analysis quantification of $\boldsymbol{D}$ and $\boldsymbol{F}(n=7)$. Error bars represent SEM; ${ }^{*} p<0.05$ using unpaired two-tailed Student's $t$ test.

\section{Ras-MAPK signaling does not influence axon growth or branching in sympathetic neurons}

Ras-MAPK signaling is known to regulate axon growth and branching in TrkA + sensory neurons (Markus et al., 2002; Newbern et al., 2011). Therefore, we next examined whether this is also true in sympathetic neurons and whether Coronin-1 plays a role. We first cultured sympathetic neurons from wild-type and Corola $^{-/-}$mice and assessed NGF-dependent p-ERK levels via immunoblot analysis (Fig. 3A). Similar to p-AKT induction, WT and Corola $a^{-/-}$neurons displayed similar levels of NGFdependent p-ERK induction (Fig. 3B). We next examined whether RAS-MAPK signaling is required for the axon growth and branching phenotypes observed in our in vitro models for axon behavior in the presence or absence of Coronin-1. To this end, we performed axon growth assays as described in Figure 1, on NGF-treated neurons from WT or Corola $a^{-/-}$mice in the presence or absence of the MEK inhibitors, PD98059 (50 $\mu \mathrm{M})$ or PD0325901 $(1 \mu \mathrm{M})$. In neurons from both WT and Corola ${ }^{-/-}$ mice MEK signaling is not required for axon growth or branching (Fig. 3C-G). These data suggest that NGF-TrkA-Ras-Erk signaling is dispensable for sympathetic axon growth in the presence or absence of Coronin-1.
Coronin-1-dependent calcium release represses NGFdependent axon growth and branching

What is the mechanism by which Coronin-1 suppresses NGFTrkA-dependent axon growth behaviors? We have previously shown that Coronin-1 is essential for NGF-dependent calcium release, whereas Coronin-1 is dispensable for MAPK and PI3K activation (Figs. 2B, 3B; Suo et al., 2014). Therefore, we speculate that the exuberant NGF-dependent axon growth behaviors observed in the absence of Coronin-1 are due to depressed NGFdependent calcium release. To determine whether Coronin-1 influences NGF-TrkA-dependent axon growth and branching via calcium signaling we used a cell-permeable calcium chelator or ionophore in neurons from WT and Coro $1 a^{-/-}$mice to inhibit or activate calcium signaling, respectively. Chelation of intracellular calcium using BAPTA-AM $(1 \mu \mathrm{M})$ had no effect on axon growth or branching in neurons from Coro $1 a^{-/-}$mice presumably because calcium levels are already low (Fig. 4A-E). However, in WT neurons BAPTA-AM increases NGF-dependent axon growth and branching to levels similar to those observed in neurons lacking Coronin-1 (Fig. 4A-E). In contrast, the calcium ionophore, ionomycin $(10 \mu \mathrm{M})$, reduced NGFdependent axon growth and branching in NGF-treated neu- 
A

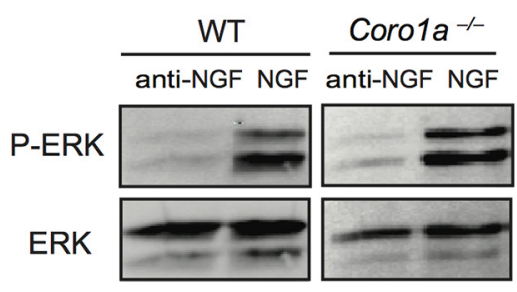

B

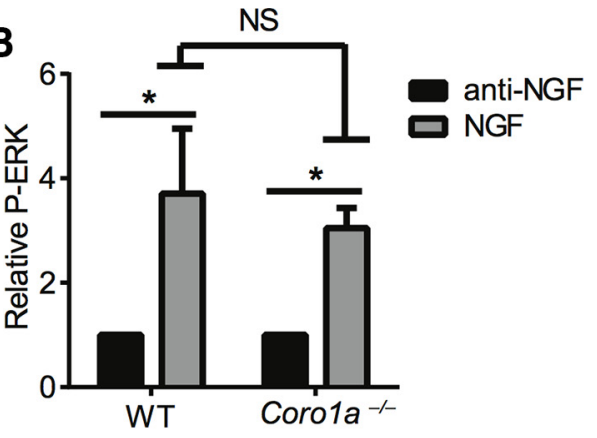

C

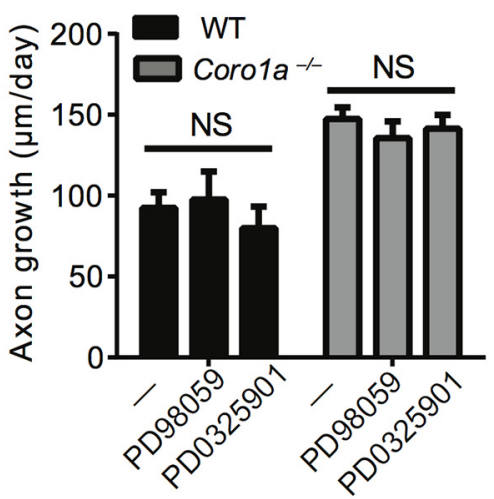

D
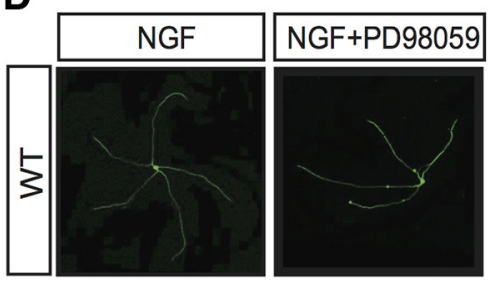

$\mathbf{F}$

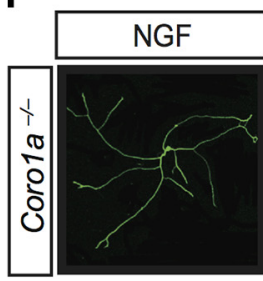

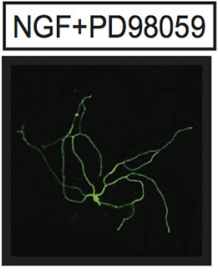

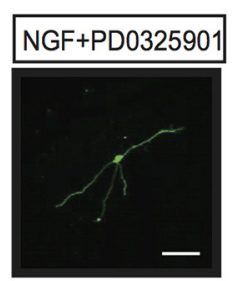

NGF+PD0325901

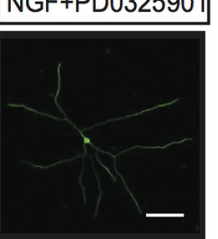

E

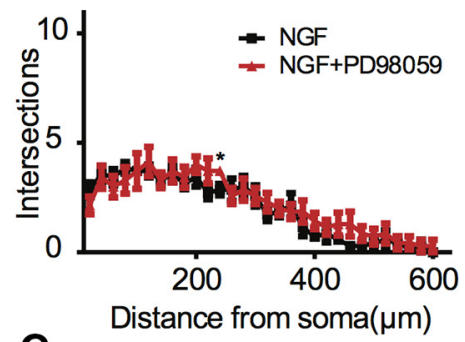

G

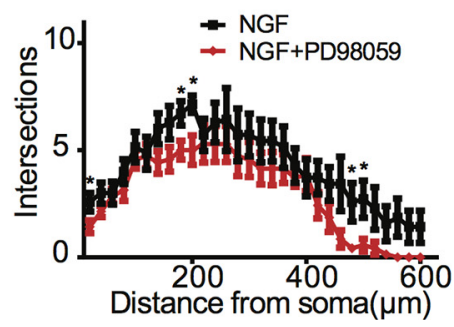

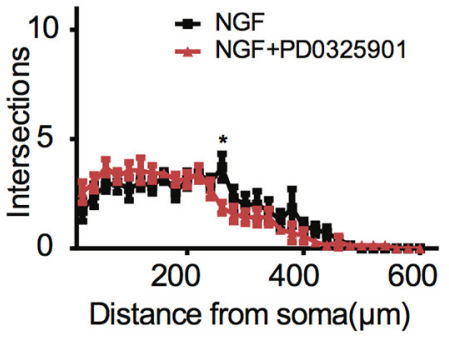

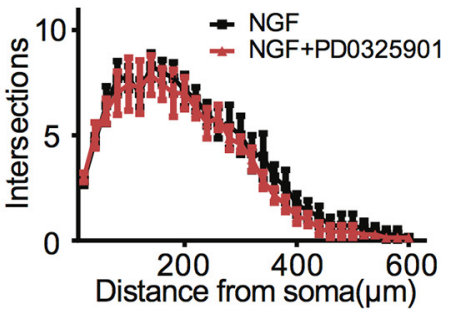

Figure 3. MAPK signaling is largely dispensable for NGF-dependent axon growth behaviors in the presence or absence of Coronin-1. A, NGF-dependent P-ERK induction in sympathetic neurons cultured from WT or Coro 1a ${ }^{-1-}$ mice for 2-3 DIV. Neurons were deprived of NGF for $17 \mathrm{~h}$ then treated with anti-NGF or NGF for 20 min followed by immunoblot analysis for P-ERK and ERK. $\boldsymbol{B}$, Quantification of the data in $\boldsymbol{A}$. Experiments were quantified with densitometry and P-ERK signals were normalized to total ERK, respectively $(n=3)$. $C$, MEK signaling is dispensable for NGF-dependent axon growth. Axon growth assays were performed on neurons from WT or Coro1a ${ }^{-/-}$mice grown in NGF ( $\left.2 \mathrm{ng} / \mathrm{ml}\right)$ with or without PD98059 (50 $\left.\mu \mathrm{M}\right)$ or PD0325901 (1 $\left.\mu \mathrm{M}\right)$ as described in Figure 1C. WT control $(n=46)$, WT with PD98059 and NGF $(n=19)$, WT with PD0325901 and NGF $(n=18)$, Coro $1 a^{-/-}$control $(n=47)$, Coro $1 a^{-/-}$with PD98059 and NGF $(n=$ 40), and Coro1a ${ }^{-/-}$with PD0325901 and NGF $(n=31) . D, F$, MEK signaling is dispensable for NGF-dependent axon branching. WT or Coro $1 a^{-/-}$mice grown in NGF (2 ng/ml) with or without PD98059 $(50 \mu \mathrm{m})$ or PD0325901 (1 $\mu \mathrm{M})$ as described in Figure 1F. Scale bar, $150 \mu \mathrm{m}$. $\boldsymbol{E}, \mathbf{G}$, Sholl analysis quantification of $\boldsymbol{D}$ and $\boldsymbol{F}(n=7)$. Scale bar, $30 \mu \mathrm{m}$. Error bars represent SEM; ${ }^{*} p<0.05$ using unpaired two-tailed Student's $t$ test.

rons from Corola $a^{-/-}$mice to levels similar to those observed in WT neurons (Fig. 4F-J). However, ionomycin had no effect on axon growth and branching in WT neurons presumably because NGF-TrkA-Coronin-1 is already driving sufficient calcium signaling to suppress these processes (Fig. $4 F-J$ ). These findings suggest that the mechanism by which Coronin-1 influences axon growth and branching is by governing NGF-dependent calcium release.

It has been previously shown that NGF-TrkA-dependent calcium release requires PLC- $\gamma 1$ (Vetter et al., 1991; Obermeier et al., 1994). Pieters and colleagues has previously shown in thymocytes that Coronin-1 interacts with and is required for PLC- $\gamma 1$ activation in response to engagement of the T-cell receptor (Mueller et al., 2008). Consistent with a similar role in neurons, we found that inhibition of PLC- $\gamma 1$ with U73122 $(1 \mu \mathrm{M})$ had no effect on NGF-dependent axon growth and branching in neurons from Corola ${ }^{-/-}$mice (Fig. $5 A-E)$. However, similar to BAPTA-AM treatment, U73122 treatment of WT neurons phenocopies the elevated NGF- dependent axon growth and branching observed in neurons lacking Coronin-1 (Fig. 5A-E). This supports the notion that PLC- $\gamma 1$ and Coronin-1 work together to support NGFdependent calcium signaling and suppress axon growth behaviors.

Coronin-1-dependent calcium signaling disinhibits GSK3 $\beta$ to repress axon growth and branching

Together with our finding that loss of Coronin-1 does not impact the ability of NGF to induce PI3K activity, we suggest that the point of cross talk between these two pathways lies several steps downstream of PI3K activation. GSK3 $\beta$ is an excellent candidate for this. PI3K activation results in an inhibitory phosphorylation event on GSK3 $\beta$, resulting in disinhibition of APC microtubule polymerization activity and promotion of axon growth and branching activity (Zhou et al., 2004; Jiang et al., 2005). Therefore, we sought to assess the role of Coronin-1 on inhibition of GSK $3 \beta$ by phosphorylation. Toward this end, we cultured sympathetic neurons from WT 
A

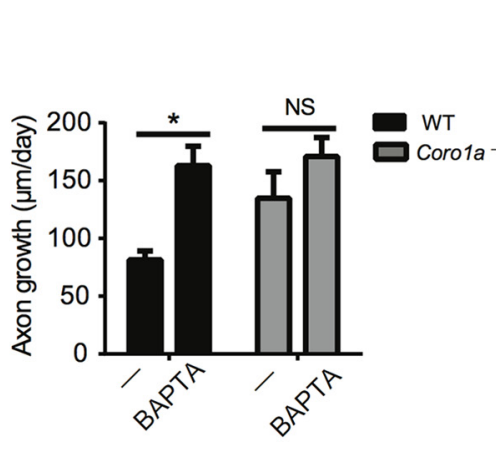

$\mathbf{F}$

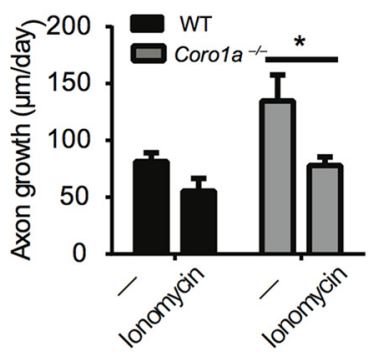

B

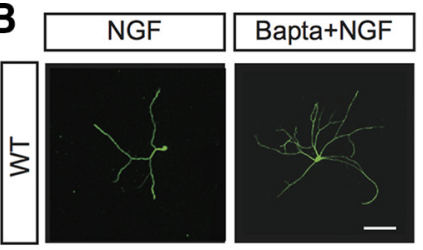

C
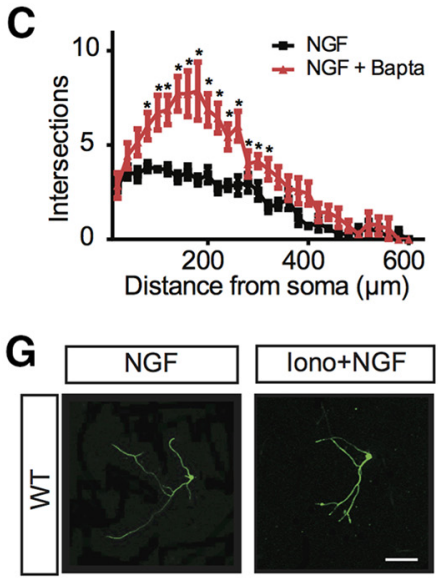

H

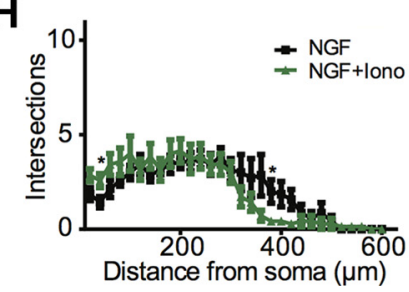

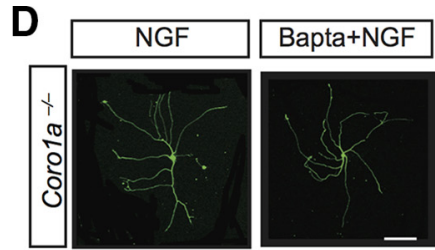

E
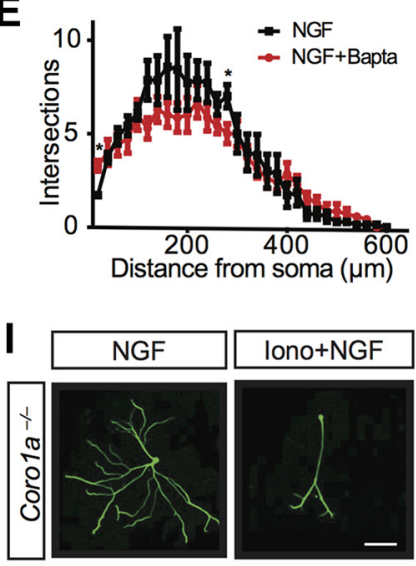

J

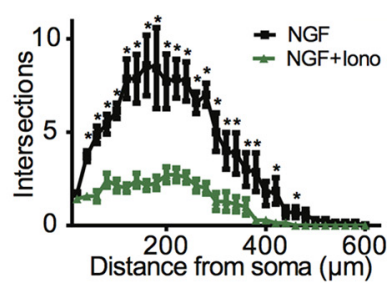

Figure 4. Coronin-1-dependent calcium signaling suppresses axon growth and branching. $A$, Chelation of calcium increases NGF-induced axon growth in WT but not Coro $1 a^{-/-}$neurons. Axon growth assays were performed on neurons from WT or Coro $1 a^{-1-}$ mice grown in NGF ( $2 \mathrm{ng} / \mathrm{ml}$ ) with or without BAPTA $(1 \mu \mathrm{m})$ as described in Figure $1 B$. WT control ( $\left.n=39\right)$, WT with BAPTA-AM and NGF $(n=65)$, Coro $1 a^{-1-}$ control $(n=20)$, and Coro 1a $a^{-1-}$ with BAPTA-AM and NGF $(n=36)$. Scale bar, $30 \mu \mathrm{m}$. B, D, Chelation of calcium increases branching in WT but not Coro $1 a^{-1-}$ neurons. Branching of WT or Coro $1 a^{-1-}$ mice grown in NGF $(2 \mathrm{ng} / \mathrm{ml})$ with or without BAPTA-AM (1 $\left.\mu \mathrm{m}\right)$ as described in Figure $1 F$. Scale bar, $150 \mu \mathrm{m}$. $\boldsymbol{C}, \boldsymbol{E}$, Sholl analysis quantification of $\boldsymbol{B}$ and $\boldsymbol{D}$ $(n=7)$. $F$, Elevated calcium suppresses NGF-induced axon growth in Coro1a ${ }^{-/-}$but not wild-type neurons. Axon growth assays were performed on neurons from WT or Coro $1 a^{-1-}$ mice grown in NGF $(2 \mathrm{ng} / \mathrm{ml})$ with or without ionomycin $(10 \mu \mathrm{m})$ as described in Figure $1 B$. WT control $(n=39)$, WT with ionomycin and NGF $(n=34)$, Coro1a ${ }^{-/-}$control $(n=20)$, and Coro1a $a^{-/-}$with ionomycin and NGF $(n=42)$. Scale bar, $30 \mu \mathrm{m}$. G, I, Elevated calcium suppresses branching in Coro 1 $a^{-\prime-}$ but not wild-type neurons. Branching of WT or Coro $1 a^{-\prime-}$ mice grown in NGF (2 ng/ml) with or without ionomycin (10 $\mu \mathrm{m})$ as described in Figure 1 F. Scale bar, $150 \mu \mathrm{m}$. $\boldsymbol{H}, \boldsymbol{J}$, Sholl analysis quantification of $\mathbf{G}$ and $\boldsymbol{I}(n=7)$. Scale bar, $30 \mu \mathrm{m}$. Error bars represent SEM; ${ }^{*} p<0.05$ using unpaired two-tailed Student's $t$ test.

and Corola $a^{-1-}$ mice and assessed NGF-dependent p-GSK3 $\beta$ levels via immunoblot analysis (Fig. 6A). Remarkably, NGF elevates p-GSK3 $\beta$ in Coro $1 a^{-/-}$but not WT neurons (Fig. $6 B$ ). We next examined whether GSK3 $\beta$ signaling is required for NGF-dependent axon growth and branching in the presence or absence of Coronin-1. To this end, we performed axon growth assays on NGF-treated neurons from WT or Corola $a^{-1-}$ mice in the presence or absence of the GSK3 $\beta$ inhibitor XIX ( $200 \mathrm{nM}$; GSKi), which is analogous to inhibitory phosphorylation of GSK3 $\beta$. The GSK3 $\beta$ inhibitor had no effect on axon growth or branching in neurons from Corola $a^{-/-}$mice but elevated these properties in WT neurons (Fig. 6C-G).These data suggest that NGF-TrkA-Coronin-1PLC- $\gamma 1$-calcium signaling suppresses axon growth and branching by disinhibiting GSK3 $\beta$.

\section{Coronin-1 regulates NGF-dependent axon growth and} branching in vivo

These in vitro data provide a clear prediction for axon growth and branching in vivo in mice lacking Coronin-1. If initiation of dampened axon growth and branching is associated with induction of Coronin-1 expression, we would expect sympathetic overgrowth and excessive branching in final target or- gans of mice lacking Coronin-1. To test this prediction, we performed whole-mount tyrosine hydroxylase staining to label sympathetic axons originating from the stellate ganglia as they innervate the heart. We examined hearts taken from WT and $\mathrm{Corola}^{-1-}$ animals at E14 and E17.5, times that are either before or after NGF-dependent Coronin-1 induction, respectively (Manousiouthakis et al., 2014; Nam et al., 2013; Suo et al., 2014). Importantly, at E14 there is no difference in axon extension along the superior vena cava ganglia, suggesting a similar role for Coronin-1 across the sympathetic nervous system (Fig. $7 A$ ). In hearts from E17.5 WT animals, the majority of axons appear at the dorsal surface of the ventricular chamber. However, in the absence of Coronin-1, axons grow much further toward the lateral walls and the apex of the heart (Fig. $7 B$ ). Additionally at ages later than E17.5, we observed a significant increase in branch number in hearts from Corola ${ }^{-1-}$ mice (Fig. 7C). Although in vitro experiments were performed using neurons from the SCG, sympathetic axons that supply the heart are derived from stellate ganglia. This suggests that, just as NGF regulates sympathetic neural growth and survival in all sympathetic end organs, the role of Coronin-1 is likely to be similarly broad. 
A

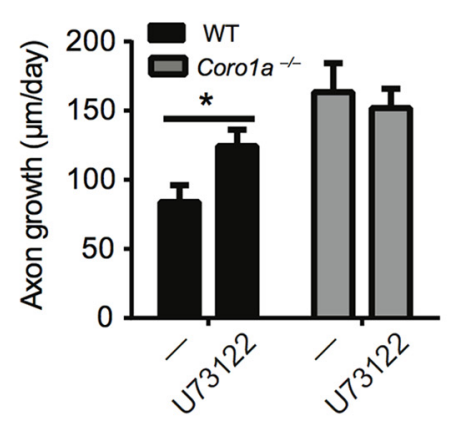

B

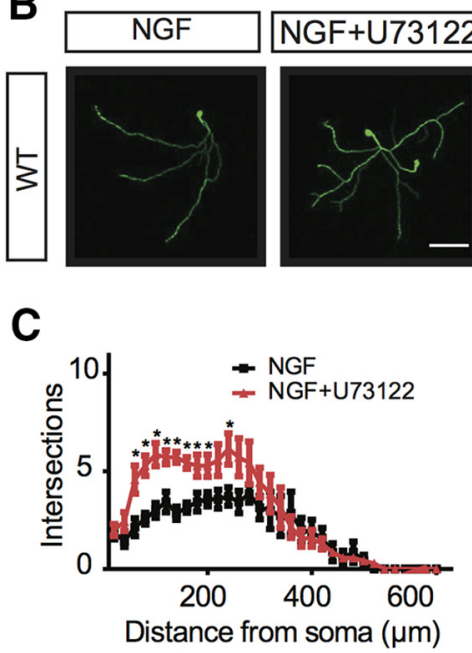

D

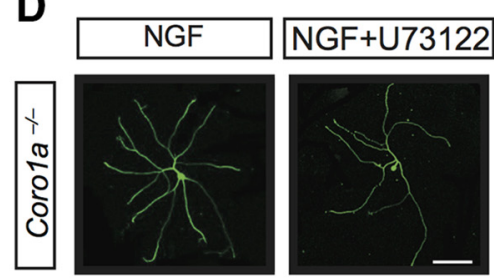

E

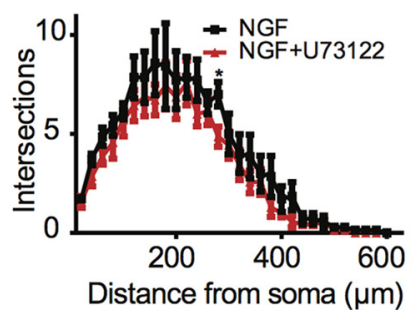

Figure 5. Coronin-1 and PLC- $\gamma 1$ work in concert to support calcium-dependent inhibition of axon growth and branching. $A$, PLC- $\gamma 1$ inhibitor has a similar effect as BAPTA-AM on NGF-induced axon growth. Axon growth assays were performed on neurons from WT or Coro 1a ${ }^{-1-}$ mice grown in NGF ( $\left.2 \mathrm{ng} / \mathrm{ml}\right)$ with or without U73122 $(1 \mu \mathrm{M})$ as described in Figure $1 B$. WT control ( $\left.n=28\right)$, WT with U73122 and NGF $(n=31)$, Coro $1 a^{-/-}$control $(n=29)$, and Coro $1 a^{-/-}$with LY294002 and NGF $(n=35)$. B, D, PLC- $\gamma 1$ inhibitor has a similar effect as BAPTA-AM on NGF-induced axon branching. Branching of WT or Coro $1 a^{-1-}$ mice grown in NGF $(2 \mathrm{ng} / \mathrm{ml})$ with or without U73122 $(1 \mu \mathrm{m})$ as described in Figure $1 F$. Scale bar, $150 \mu \mathrm{m}$. C, $\boldsymbol{E}$, Sholl analysis quantification of $\boldsymbol{B}$ and $\boldsymbol{D}$ $(n=7)$. Error bars represent SEM; ${ }^{*} p<0.05$ using unpaired two-tailed Student's $t$ test.

A

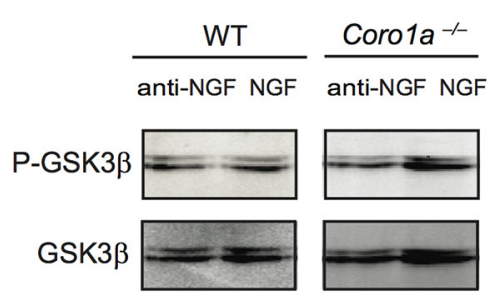

B

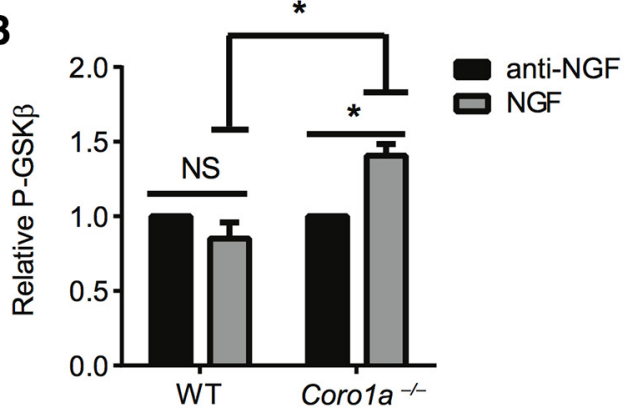

C

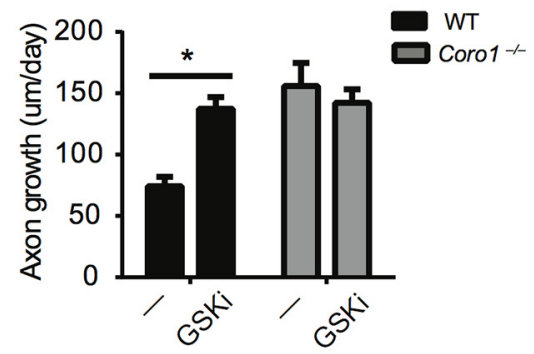

D

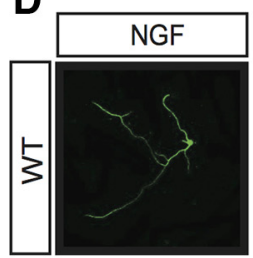

E

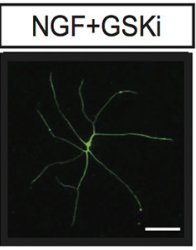

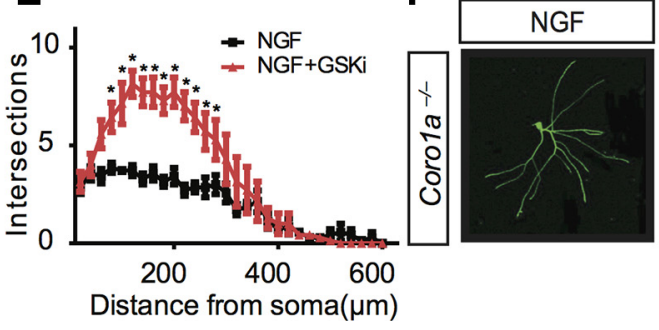

G

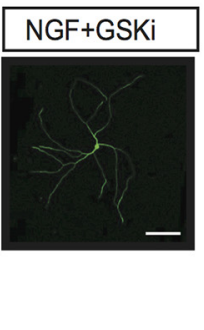

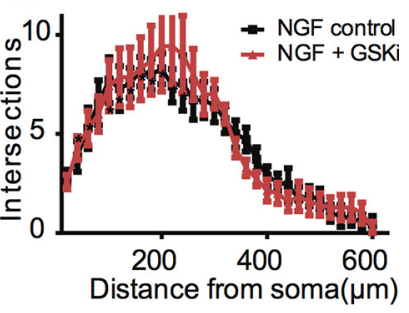

Figure 6. GSK3 $\beta$ signaling dampens NGF-dependent axon growth and branching in the presence of Coronin-1.A, NGF-dependent P-GSK3 $\beta$ induction in sympathetic neurons cultured from WT or Coro $1 a^{-1-}$ mice for 2-3 DIV. Neurons were deprived of NGF for $17 \mathrm{~h}$ then treated with anti-NGF or NGF for 20 min followed by immunoblot analysis for P-GSK3 $\beta$ and GSK3 $\beta$. $\boldsymbol{B}$, Quantification of data in $\boldsymbol{A}$. Experiments were quantified with densitometry and P-GSK3 $\beta$ signals were normalized to total GSK3 $\beta$, respectively $(n=3)$. C, GSK3 $\beta$ signaling is required to inhibit NGF-induced axon growth in WT but not Coro $1 a^{-/-}$neurons. Axon growth assays were performed on neurons from WT or Coro $1 a^{-1-}$ mice grown in NGF (2 ng/ml) with or without GSKi (GSK3 $\beta$ inhibitor XIX $200 \mathrm{~nm}$ ) as described in Figure 1B. WT control $(n=23)$, WT with GSKi and NGF $(n=23)$, Coro 1a $a^{-1-}$ control $(n=14)$, and Coro1a ${ }^{-/-}$with GSKi and NGF $(n=16)$. D, $F$, GSK3 $\beta$ signaling is required to inhibit NGF-induced axon branching in WT but not Coro $1 a^{-1-}$ neurons. Branching of WT or Coro $1 a^{-1-}$ mice grown in NGF $(2 \mathrm{ng} / \mathrm{ml})$ with or without GSKi as described in Figure 1F. Scale bar, $150 \mu \mathrm{m}$. $\boldsymbol{E}$, $\boldsymbol{G}$, Sholl analysis quantification of $\boldsymbol{D}$ and $\boldsymbol{F}(n=7)$. Error bars represent SEM; ${ }^{*} p<0.05$ using unpaired two-tailed Student's $t$ test.

\section{Discussion}

Here we examine the role of Coronin-1 in sympathetic axon growth and branching. Because Coronin-1 expression in sympathetic neurons is dependent on NGF at the final target (Suo et al., 2014), we speculate that Coronin-1 is a physiological switch involved in interpreting NGF-TrkA signaling in at least two different axon growth states during final target innervation. (1) The early innervation stage when axons experience local NGF-TrkA signaling before Coronin-1 expression and display smaller growth cones, accelerated axon growth, and increased branching in a PI3K-dependent manner (Fig. $8 A$ ). As neurons effectively compete for target-derived neurotrophic factors, they begin to engage transcriptionally mediated feedback loops (Deppmann et al., 2008; Suo et al., 2014) and neurons that are "winning" the competition for survival upregulate Coronin-1. We suggest that the duration of this early stage of final target innervation is de- 
A
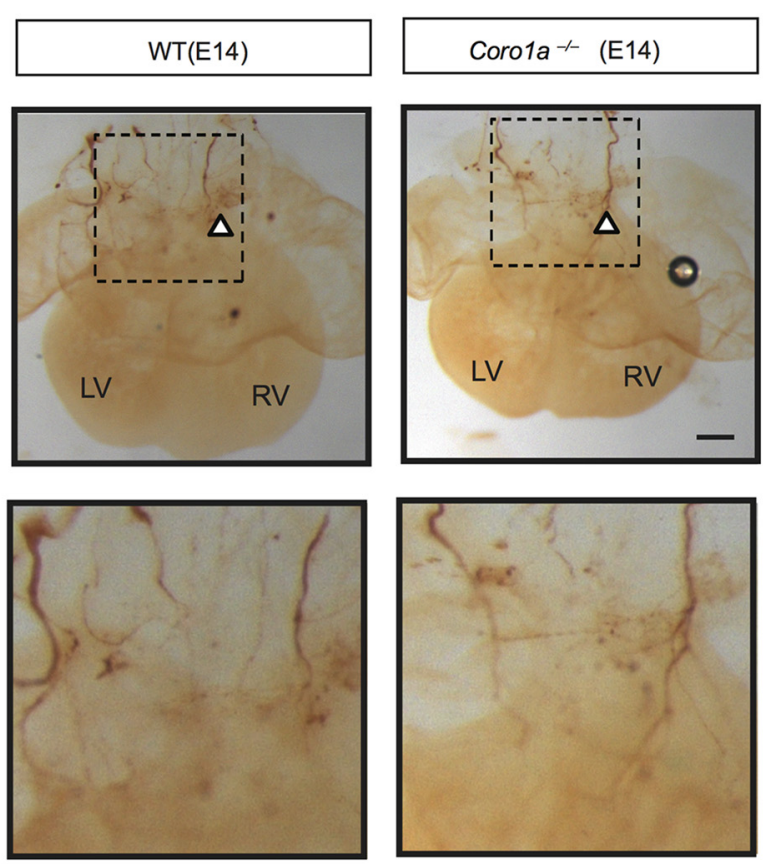

B
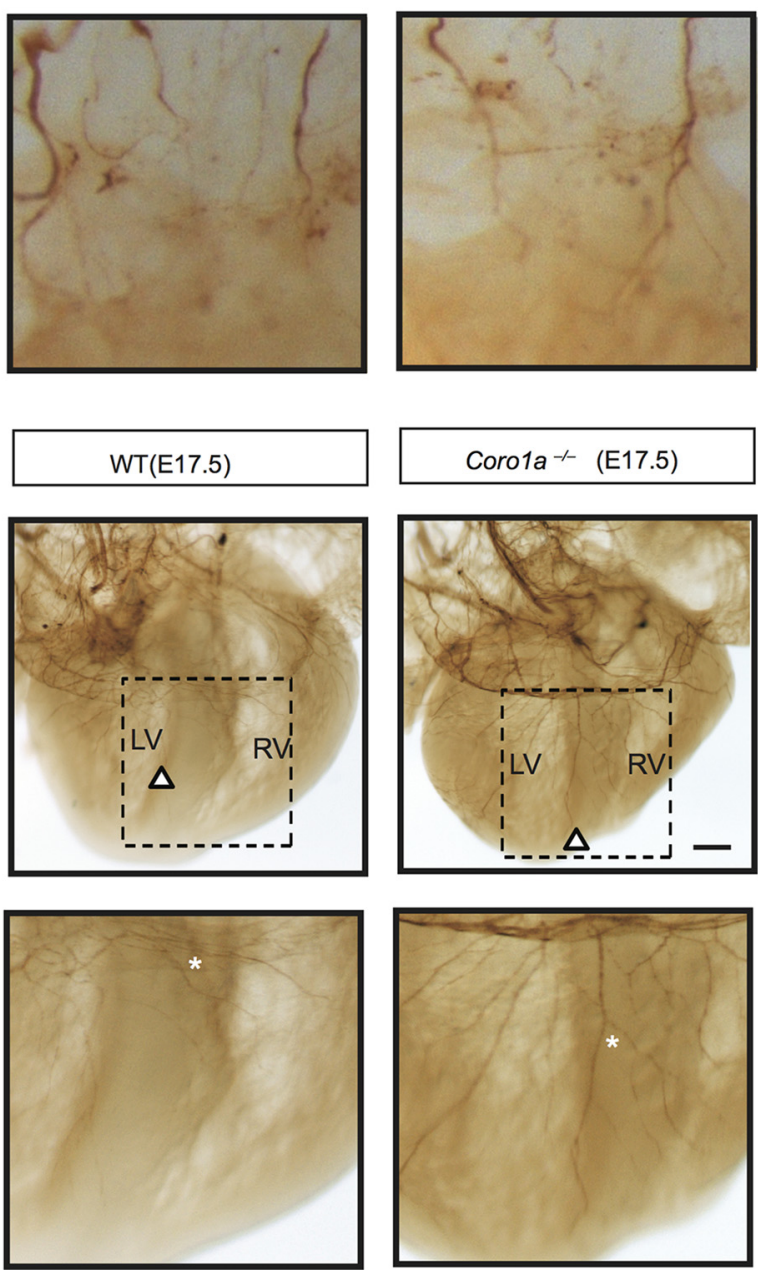

Coro1a $^{-1}(\mathrm{E} 17.5)$
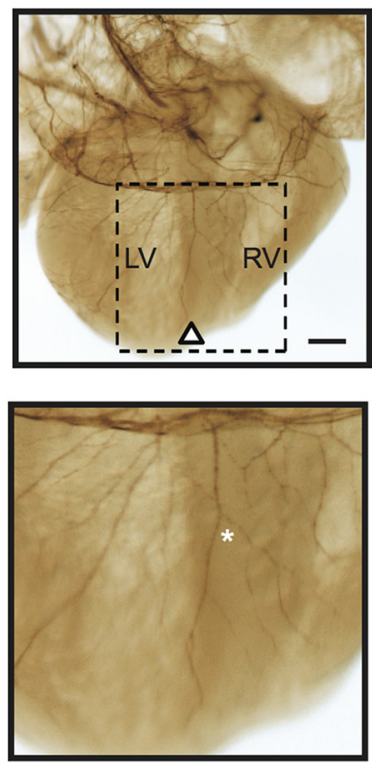

C

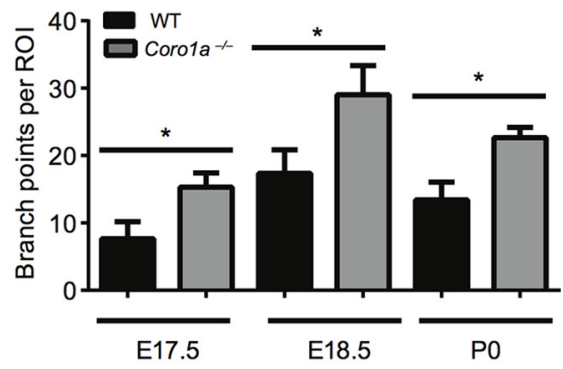

Figure 7. Loss of Coronin-1 results in excess growth and branching in vivo. A, Whole-mount tyrosine hydroxylase immunostaining of sympathetic fibers in E14 hearts from WT and Coro $1 a^{-/-}$ mice. Higher magnification images are shown below. White arrows indicate sympathetic axon terminals. Scale bar, $200 \mu \mathrm{m}$. B, Whole-mount tyrosine hydroxylase immunostaining of sympathetic fibers in E17.5 hearts from WT and Coro1 $a^{-1-}$ mice. Higher magnification images are shown below. White arrows indicate sympathetic axon terminals. White stars indicate sympathetic axon branched $(n=3)$. Scale bar, $200 \mu \mathrm{m}$. C, Quantification of axon branch points per region of interest from E17.5, E18.5, and P0 heart pictures $(n=3)$. Error bars represent SEM; ${ }^{*} p<0.05$ using unpaired two-tailed Student's $t$ test. LV, left ventricle; RV, right ventricle.

pendent on the lag between initial exposure to target-derived NGF and expression of Coronin-1 (and perhaps other genes). Indeed this interval may be as long as $2-4 \mathrm{~d}$ since sympathetic axons begin to infiltrate many of their final targets by E14.5 and begin expressing Coronin- 1 between E15.5 and E18.5 followed by peak expression at P0 (Suo et al., 2014). (2) The late, final target innervation stage corresponds to Coronin-1 upregulation, which increases NGF-induced calcium release and depresses axon growth and branching by suppressing signaling downstream of PI3K resulting in disinhibition of GSK3 $\beta$ (Fig. $8 B$ ). The presence of Coronin-1 slows but does not completely halt growth and branching, which is likely important to support continued coverage of end organs as they grow. We speculate that axon growth and branching in neurons that are "losing" the competition for neurotrophic factor will be slower to induce Coronin-1 expression and will experience a longer early stage, remaining highly active until they either find a sufficient concentration of NGF to support survival or are eliminated via apoptosis between E18.5 and P0. This may provide a general logic for how axons switch their behaviors during developmental wiring of the nervous system. 


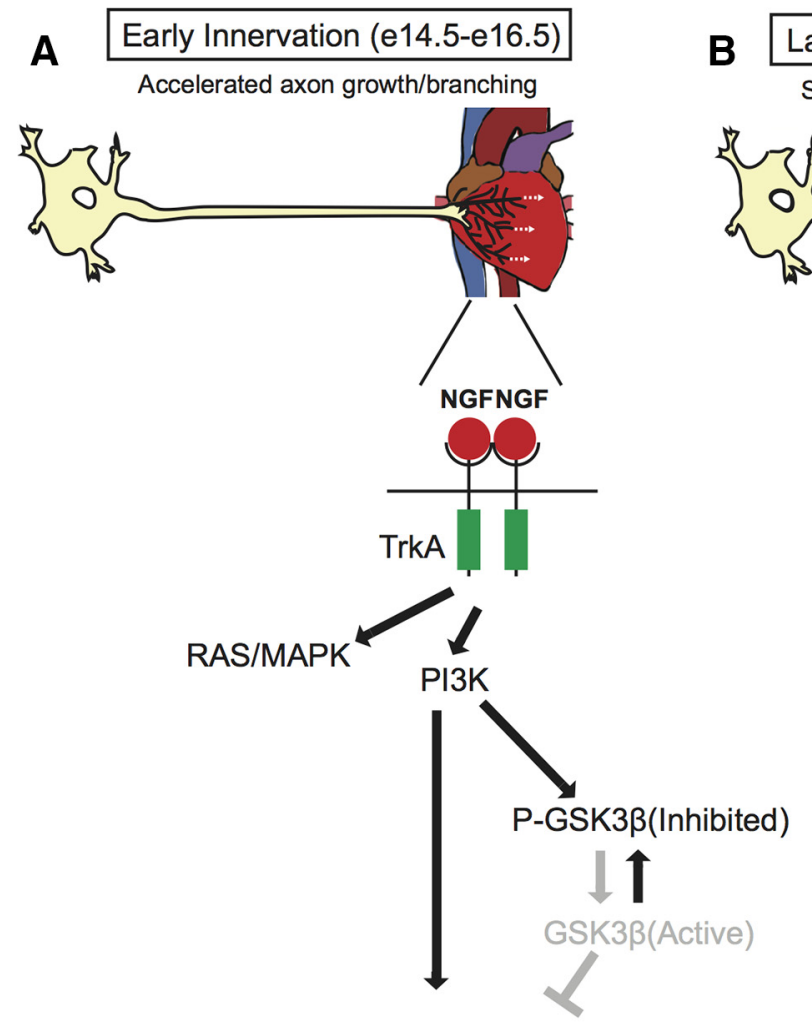

Growth and Branching
B $\frac{\text { Late Innervation (e16.5-p0) }}{\text { Slowed axon growth/branching }}$
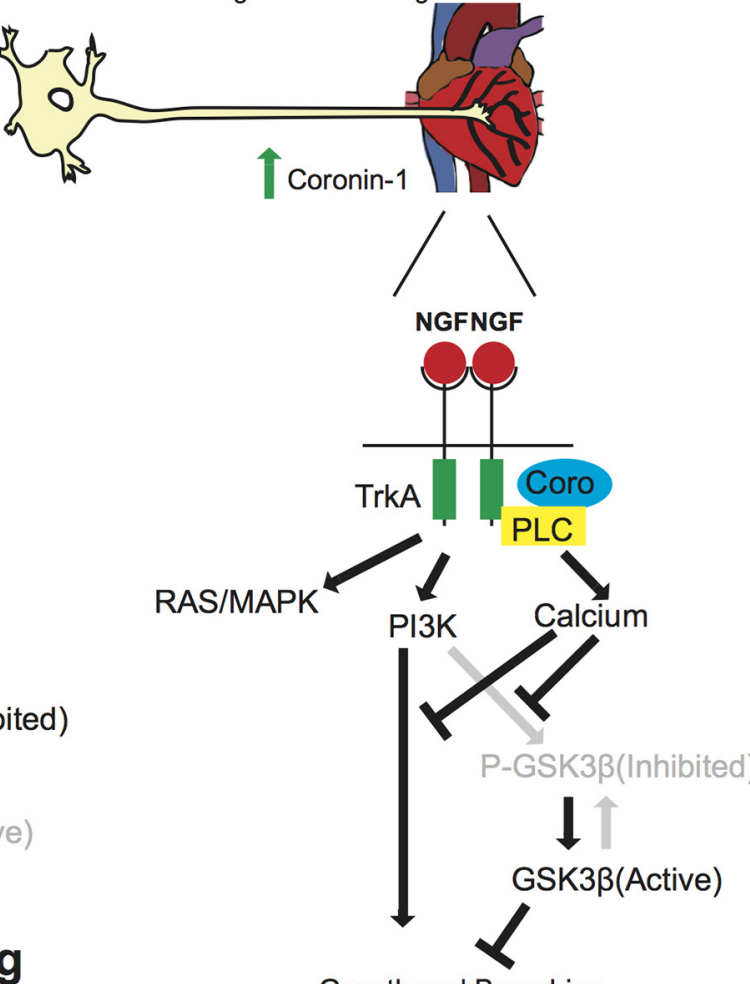

Growth and Branching

Figure 8. Model for Coronin-1 function in defining two stages of final target innervation. $A$, Model for axon behavior in the early innervation stage: NGF-TrkA signaling in the absence of Coronin-1. NGF-TrkA acts via PI3K to promote exuberant axon branching and axon growth. $\boldsymbol{B}$, Model for axon behavior in the late innervation stage: NGF-TrkA signaling in the presence of Coronin-1 increases calcium presumably through PLC $\gamma 1$, which inhibits axon growth and branching by suppressing signaling downstream PI3K.

Axon growth in sympathetic axons can be driven through local signaling in distal axons (Campenot, 1977). Based on previously reported kinetics of NGF-TrkA internalization, we speculate that much of the NGF-dependent local signaling emanates from an endosomal platform in distal axons (Kuruvilla et al., 2004; Chen et al., 2005; Harrington et al., 2011). The notion that Coronin-1 expression and association with the NGF-TrkA endosome are both NGF dependent (Suo et al., 2014) suggests that the constituents of the signaling endosome platform are quite dynamic. Coronin-1 is likely to recruit or influence several other endosomal proteins. For example, our data together with previous studies suggest that although PLC- $\gamma 1$ may be immediately recruited to activated TrkA via its $\mathrm{SH} 2$ domain, it is not functional until Coronin-1 is recruited during the late stage of final target innervation (Ohmichi et al., 1991; Mueller et al., 2008). It is intriguing to speculate that neurotrophin-induced calcium release occurs as a function of effector proteins associated with post-endocytic TrkA. It has been shown that calcium modulation is directly linked to axon growth rate and turning behavior (Mattson and Kater, 1987; Song et al., 1997). Low calcium levels correspond to rapid growth and decreased turning while high calcium levels correspond to slowed growth, consistent with Coronin-1 function in sympathetic neurons and is suggestive of a general principal in axon growth (Song et al., 1997; Robles et al., 2003).

Beyond influencing signaling, endosomally associated Coronin-1 may directly influence cytoskeleton dynamics by inhibiting actin nucleation protein(s) Arp2/3 (Rodal et al., 2005). Coronin family members have also been reported to associate with the actinsevering protein cofilin, which interacts with the signaling endosome and regulates proper NGF-TrkA trafficking (Gandhi et al., 2009; Harrington et al., 2011). Whether and how Coronin-1 recruits and/or regulates endosomal proteins involved in cytoskeletal modification will be the subject of future inquiry.

TrkA signaling has also been shown to influence sensory neuron axon growth and branching (Klein et al., 1994; Markus et al., 2002; Zhou et al., 2004; Wheeler et al., 2014). Despite similar trophic dependencies between sympathetic and nociceptive sensory neurons, they appear to use classic TrkA-dependent signaling pathways differently to control axon growth. While inhibition of PI3K influences axon growth in wild-type sensory neurons, similar inhibition is only observed in the absence of Coronin-1 and calcium signaling in sympathetic neurons (Markus et al., 2002; Zhou et al., 2004). This may indicate a fundamentally different role for TrkA-dependent calcium signaling between peripheral neuron subtypes. On the other hand, we find that inhibition of Ras-MAPK signaling has little to no effect on growth and branching of sympathetic axons, which is consistent with recent in vivo studies examining this pathway in sensory axons (Newbern et al., 2011). Future studies on these differences in what have been widely assumed to be relatively similar PNS neuron populations will provide an opportunity to dissect key downstream pathways and better understand the logic of axon behavior as they transition from path finding to target innervation. 


\section{References}

Arévalo JC, Wu SH (2006) Neurotrophin signaling: many exciting surprises! Cell Mol Life Sci 63:1523-1537. CrossRef

Argiro V, Bunge MB, Johnson MI (1984) Correlation between growth form and movement and their dependence on neuronal age. J Neurosci 4:30513062. Medline

Bray D, Chapman K (1985) Analysis of microspike movements on the neuronal growth cone. J Neurosci 5:3204-3213. Medline

Campenot RB (1977) Local control of neurite development by nerve growth factor Cell Biology: Campenot. Proc Natl Acad Sci U S A 74:4516-4519. CrossRef Medline

Carmeliet P (2003) Blood vessels and nerves: common signals, pathways and diseases. Nat Rev Genet 4:710-720. CrossRef Medline

Chen ZY, Ieraci A, Tanowitz M, Lee FS (2005) A novel endocytic recycling signal distinguishes biological responses of Trk neurotrophin receptors. Mol Biol Cell 16:5761-5772. CrossRef Medline

Deppmann CD, Mihalas S, Sharma N, Lonze BE, Niebur E, Ginty DD (2008) A model for neuronal competition during development. Science 320: 369-373. CrossRef Medline

Enomoto H, Crawford PA, Gorodinsky A, Heuckeroth RO, Johnson EM Jr, Milbrandt J (2001) RET signaling is essential for migration, axonal growth and axon guidance of developing sympathetic neurons. Development 128:3963-3974. Medline

Gandhi M, Achard V, Blanchoin L, Goode BL (2009) Coronin switches roles in actin disassembly depending on the nucleotide state of actin. Mol Cell 34:364-374. CrossRef Medline

Glebova NO, Ginty DD (2004) Heterogeneous requirement of NGF for sympathetic target innervation in vivo. J Neurosci 24:743-751. CrossRef Medline

Godement P, Wang LC, Mason CA (1994) Retinal axon divergence in the optic chiasm: dynamics of growth cone behavior at the midline. J Neurosci 14:7024-7039. Medline

Gomez TM, Zheng JQ (2006) The molecular basis for calcium-dependent axon pathfinding. Nat Rev Neurosci 7:115-125. CrossRef Medline

Goold RG, Gordon-Weeks PR (2004) Glycogen synthase kinase 3beta and the regulation of axon growth. Biochem Soc Trans 32:809-811. CrossRef Medline

Harrington AW, St Hillaire C, Zweifel LS, Glebova NO, Philippidou P, Halegoua S, Ginty DD (2011) Recruitment of actin modifiers to TrkA endosomes governs retrograde NGF signaling and survival. Cell 146:421-434. CrossRef Medline

Henley J, Poo MM (2004) Guiding neuronal growth cones using Ca2+ signals. Trends Cell Biol 14:320-330. CrossRef Medline

Jayachandran R, Sundaramurthy V, Combaluzier B, Mueller P, Korf H, Huygen K, Miyazaki T, Albrecht I, Massner J, Pieters J (2007) Survival of mycobacteria in macrophages is mediated by coronin 1-dependent activation of calcineurin. Cell 130:37-50. CrossRef Medline

Jayachandran R, Liu X, Bosedasgupta S, Müller P, Zhang CL, Moshous D, Studer V, Schneider J, Genoud C, Fossoud C, Gambino F, Khelfaoui M, Müller C, Bartholdi D, Rossez H, Stiess M, Houbaert X, Jaussi R, Frey D, Kammerer RA, et al. (2014) Coronin 1 Regulates Cognition and Behavior through Modulation of cAMP/Protein Kinase A Signaling. PLoS Biol 12:e1001820. CrossRef Medline

Jiang H, Guo W, Liang X, Rao Y (2005) Both the establishment and the maintenance of neuronal polarity require active mechanisms: critical roles of GSK-3beta and its upstream regulators. Cell 120:123-135. CrossRef Medline

Klein R, Silos-Santiago I, Smeyne RJ, Lira SA, Brambilla R, Bryant S, Zhang L, Snider WD, Barbacid M (1994) Disruption of the neurotrophin-3 receptor gene trkC eliminates la muscle afferents and results in abnormal movements. Nature 368:249-251. CrossRef Medline

Kohn J, Aloyz RS, Toma JG, Haak-Frendscho M, Miller FD (1999) Functionally antagonistic interactions between the TrkA and p75 neurotrophin receptors regulate sympathetic neuron growth and target innervation. J Neurosci 19:5393-5408. Medline

Kuruvilla R, Zweifel LS, Glebova NO, Lonze BE, Valdez G, Ye H, Ginty DD (2004) A neurotrophin signaling cascade coordinates sympathetic neuron development through differential control of TrkA trafficking and retrograde signaling. Cell 118:243-255. CrossRef Medline

Magariños AM, McEwen BS, Saboureau M, Pevet P (2006) Rapid and re- versible changes in intrahippocampal connectivity during the course of hibernation in European hamsters. Proc Natl Acad Sci U S A 103:1877518780. CrossRef Medline

Manousiouthakis E, Mendez M, Garner MC, Exertier P, Makita T (2014) Venous endothelin guides sympathetic innervation of the developing mouse heart. Nat Commun 5:3918. CrossRef Medline

Markus A, Zhong J, Snider WD (2002) Raf and akt mediate distinct aspects of sensory axon growth. Neuron 35:65-76. CrossRef Medline

Marsick BM, Letourneau PC (2011) Labeling F-actin barbed ends with rhodamine-actin in permeabilized neuronal growth cones. J Vis Exp pii: 2409. CrossRef Medline

Mattson MP, Kater SB (1987) Calcium regulation of neurite cone motility. J Neurosci 7:4034-4043. Medline

Mueller P, Massner J, Jayachandran R, Combaluzier B, Albrecht I, Gatfield J, Blum C, Ceredig R, Rodewald HR, Rolink AG, Pieters J (2008) Regulation of T cell survival through coronin-1-mediated generation of inositol1,4,5-trisphosphate and calcium mobilization after $\mathrm{T}$ cell receptor triggering. Nat Immunol 9:424-431. CrossRef Medline

Nam J, Onitsuka I, Hatch J, Uchida Y, Ray S, Huang S, Li W, Zang H, RuizLozano P, Mukouyama YS (2013) Coronary veins determine the pattern of sympathetic innervation in the developing heart. Development 140: 1475-1485. CrossRef Medline

Newbern JM, Li X, Shoemaker SE, Zhou J, Zhong J, Wu Y, Bonder D, Hollenback S, Coppola G, Geschwind DH, Landreth GE, Snider WD (2011) Specific functions for ERK/MAPK signaling during PNS development. Neuron 69:91-105. CrossRef Medline

Obermeier A, Bradshaw RA, Seedorf K, Choidas A, Schlessinger J, Ullrich A (1994) Neuronal differentiation signals are controlled by nerve growth factor receptor/Trk binding sites for SHC and PLC gamma. EMBO J 13:1585-1590. Medline

Ohmichi M, Deckert SJ, Pang L, Saltiel AR (1991) Phospholipase C-gamma 1 directly associates with the p70 trk oncogene product through its src homology domains. J Biol Chem 266:14858-14861. Medline

Park JW, Vahidi B, Taylor AM, Rhee SW, Jeon NL (2006) Microfluidic culture platform for neuroscience research. Nat Protoc 1:2128-2136. CrossRef Medline

Robles E, Huttenlocher A, Gomez TM (2003) Filopodial calcium transients regulate growth cone motility and guidance through local activation of calpain. Neuron 38:597-609. CrossRef Medline

Rodal AA, Sokolova O, Robins DB, Daugherty KM, Hippenmeyer S, Riezman H, Grigorieff N, Goode BL (2005) Conformational changes in the Arp2/3 complex leading to actin nucleation. Nat Struct Mol Biol 12:26-31. CrossRef Medline

Seeley PJ, Greene LA (1983) Short-latency local actions of nerve growth factor at the growth cone. Proc Natl Acad Sci U S A 80:2789-2793. CrossRef Medline

Sharma N, Deppmann CD, Harrington AW, St Hillaire C, Chen ZY, Lee FS, Ginty DD (2010) Long-distance control of synapse assembly by targetderived NGF. Neuron 67:422-434. CrossRef Medline

Singh KK, Park KJ, Hong EJ, Kramer BM, Greenberg ME, Kaplan DR, Miller FD (2008) Developmental axon pruning mediated by BDNF-p75NTRdependent axon degeneration. Nat Neurosci 11:649-658. CrossRef Medline

Song HJ, Ming GL, Poo MM (1997) cAMP-induced switching in turning direction of nerve growth cones. Nature 388:275-279. CrossRef Medline

Suo D, Park J, Harrington AW, Zweifel LS, Mihalas S, Deppmann CD (2014) Coronin-1 is a neurotrophin endosomal effector that is required for developmental competition for survival. Nat Neurosci 17:36-45. CrossRef Medline

Vetter ML, Martin-Zanca D, Parada LF, Bishop JM, Kaplan DR (1991) Nerve growth factor rapidly stimulates tyrosine phosphorylation of phospholipase C-gamma 1 by a kinase activity associated with the product of the trk protooncogene. Proc Natl Acad Sci U S A 88:5650-5654. Medline

Wheeler MA, Heffner DL, Kim S, Espy SM, Spano AJ, Cleland CL, Deppmann CD (2014) TNF- $\alpha /$ TNFR1 signaling is required for the development and function of primary nociceptors. Neuron 82:587-602. CrossRef Medline

Zareen N, Greene L (2009) Protocol for culturing sympathetic neurons from rat superior cervical ganglia (SCG). J Vis Exp pii:988. CrossRef Medline

Zhou FQ, Zhou J, Dedhar S, Wu YH, Snider WD, Hill C, Carolina N (2004) NGF-induced axon growth is mediated by localized inactivation of GSK3 beta and functions of the microtubule plus end binding protein APC. Neuron 42:897-912. CrossRef Medline 